


\section{Antisemitism and the left}

\section{MANCHESTER 1824}

Manchester University Press 
Robert Fine and Philip Spencer - 9781526104960 Downloaded from manchesterhive.com at 04/26/2023 10:33:31AM via free access 


\section{Antisemitism and the left \\ On the return of the Jewish question ROBERT FINE AND PHILIP SPENCER}

Manchester University Press 
Copyright () Robert Fine and Philip Spencer 2017

The rights of Robert Fine and Philip Spencer to be identified as the authors of this work have been asserted by them in accordance with the Copyright, Designs and Patents Act 1988.

Published by Manchester University Press

Altrincham Street, Manchester M1 7JA

www.manchesteruniversitypress.co.uk

British Library Cataloguing-in-Publication Data

A catalogue record for this book is available from the British Library

Library of Congress Cataloging-in-Publication Data applied for

ISBN 9781526104953 hardback

ISBN 9781526104977 paperback

ISBN 9781526104960 open access

First published 2017

An electronic version of this book is also available under a Creative Commons (CC-BY-NC) license

The publisher has no responsibility for the persistence or accuracy of URLs for any external or third-party internet websites referred to in this book, and does not guarantee that any content on such websites is, or will remain, accurate or appropriate.

Typeset

by Toppan Best-set Premedia Limited

Printed in Great Britain

by Bell \& Bain Ltd, Glasgow 